\section{No podemos pasarnos otros 40 años hablando de los 40 años}

El día en que escribo, así como el día en que ustedes lean esta nota editorial, cerca de 5000 personas adquirirán HIV en el mundo, entre ellas, 500 niñas y niños. Hoy 2600 personas morirán a causa del sida. Esta semana, 7000 mujeres de entre 15 y 24 años se habrán infectado.

Cuando hace 40 años veíamos los primeros casos de lo que después sabríamos que era la infección por HIV, pensar en terminar con la epidemia parecía una utopía. En medio de una de las emergencias de salud más importantes de la historia, la incógnita era si alguna vez iba a terminar. Era una ilusión más cercana a una fantasía que a una realidad alcanzable. Todos los días veíamos contraer el HIV y morir a cada vez más personas como consecuencia del sida. A la epidemia descontrolada se sumaban el estigma y la discriminación con que se trataba a los pacientes fuera y, aún más grave, dentro del sistema de salud.

En estos 40 años hemos avanzado enormemente en nuestros conocimientos desde las ciencias básicas hasta las ciencias sociales, incluyendo, de manera destacada, los avances en el tratamiento antirretroviral.

Sin embargo, cuarenta años después de la descripción de los primeros casos, la enfermedad por HIV, que es prevenible y tratable, sigue siendo transmitida y constituye una importante causa de muerte, particularmente para las poblaciones más vulnerables.

¿Por qué no controlamos el HIV si es prevenible y tratable? ¿Por qué no impedimos muertes evitables? ¿Qué hace falta para controlar la epidemia?

La respuesta es muy simple: voluntad política, liderazgo e inversión eficiente.

El mundo se puso como objetivo controlar el HIV en 2020. No se pudo. Pasó al 2030. ¿Se podrá? Cumplir esta meta se lo debemos a los 39 millones de personas que murieron a causa de la enfermedad hasta ahora, y además es un compromiso ineludible con las personas que hoy viven con el virus y con las generaciones que vienen.
Sin embargo, aun cumpliendo los objetivos de ONUSIDA del $90 / 90 / 90$, el $27 \%$ de las personas que viven con el virus no tendrían su carga viral indetectable, y por lo tanto estarían en riesgo de enfermar, morir y transmitir la infección. Aun si alcanzáramos el 90/90/90 sería insuficiente para los casi 10 millones que seguirían con su viremia no controlada. La expansión universal del TARV es un imperativo ético, pero también sanitario.

Cada día perdido lo pagan miles de mujeres, hombres y niños con sus vidas.

El diagnóstico y el tratamiento tempranos combinados con los beneficios de la terapia antirretroviral, permiten que las personas con HIV tengan una calidad de vida similar a la de que aquellas que no tienen el virus. Así, se reducen las muertes relacionadas con el sida, y a la vez disminuyen las posibilidades de nuevas infecciones a medida que las personas con HIV alcanzan niveles indetectables de virus en la sangre. Hoy quien accede a y cumple con un tratamiento exitoso ya no transmite la infección a su pareja (l=I).

En nuestro país, el acceso al diagnóstico y tratamiento es gratuito por ley. La seguridad social, las prepagas y, principalmente, el Estado nacional brindan estos servicios... a los que los solicitan. Así, el sistema reproduce su carácter darwiniano, seleccionando a los más aptos. ¿Quiénes son los más aptos? Los que tienen tiempo, salud suficiente y fondos para costearse el transporte para ir a los centros de salud. Los que no dependen de cobrar el presentismo y quienes no lo perderían en caso de ir al hospital en el estrecho horario que suelen ofrecer nuestros sistemas, más adaptados a los horarios de los equipos de salud que a las necesidades de los pacientes. De esta manera, el sistema de salud reproduce y amplifica el más importante determinante de enfermedad en nuestras sociedades: la desigualdad social. Finalmente, quienes no vienen a tiempo, llegan al sistema de salud. Los traen en ambulancia, con su enfermedad avanzada.

¿Cómo abordar esta situación? Descentralizando el testeo, acercando la salud a las personas en vez de esperar pasivamente que vengan. Masificando los test rápidos, promoviendo el autotest, eliminando las barreras burocráticas que dificultan el testeo, implementando el tratamiento inmediato (en lo posible el mismo día) y teniendo una política proactiva de retención en el cuidado y recuperación de las personas perdidas en su seguimiento. Implementar el tratamiento como eje central de la prevención en el marco de un conjunto que incluya otras acciones como la educación sexual, la promoción del uso de preservativos, la PrEP, la reducción de daños y el 
combate al estigma y la discriminación es hoy más relevante que nunca.

En nuestro país se estima que más del $17 \%$ de las personas que viven con HIV desconocen su situación. Son, en teoría, alrededor de 22.000 individuos en riesgo de enfermar, transmitir y morir.

Los lectores con "DNI de números bajos" recordarán una película española, llamada Solos en la madrugada, donde José Sacristán interpreta a un conductor de radio que se dirige a su audiencia después de la muerte del dictador Francisco Franco. $Y$ les dice: "No podemos pasarnos los próximos 40 años hablando de los 40 años de dictadura".

Parece aplicable a nuestra actitud frente a la epidemia. Debemos decidir si queremos ser parte de la solución. Si no lo hacemos, seremos parte del problema.

No podemos pasarnos otros 40 años hablando de los 40 años. Es hora de actuar. El desafío para todos es acortar los plazos y que el acceso al diagnóstico y al tratamiento oportuno sea universal, para controlar la epidemia de HIV/sida de una vez y para siempre.

\section{Pedro Cahn}

Director Científico

Fundación Huésped 